OPEN ACCESS

Edited by:

Yan Zeng,

Chinese Academy of Sciences

(CAS), China

Reviewed by:

Michael 't Sas-Rolfes,

University of Oxford, United Kingdom

Richard Patrick Reading,

Butterfly Pavilion, United States

${ }^{*}$ Correspondence:

Hubert Cheung

h.cheung@uqconnect.edu.au

tORCID:

Hubert Cheung orcid.org/0000-0002-5918-9907

Lorraine Mazerolle orcid.org/0000-0002-3691-8644

Hugh P. Possingham orcid.org/0000-0001-7755-996X

Duan Biggs orcid.org/0000-0003-3177-4677

Specialty section:

This article was submitted to Conservation and Restoration

Ecology,

a section of the journa

Frontiers in Ecology and Evolution

Received: 17 September 2020

Accepted: 12 January 2021

Published: 21 April 2021

Citation:

Cheung $\mathrm{H}$, Mazerolle L

Possingham HP and Biggs D (2021)

China's Legalization of Domestic

Rhino Horn Trade: Traditional Chinese

Medicine Practitioner Perspectives and the Likelihood of Prescription.

Front. Ecol. Evol. 9:607660.

doi: 10.3389/fevo.2021.607660

\section{China's Legalization of Domestic Rhino Horn Trade: Traditional Chinese Medicine Practitioner Perspectives and the Likelihood of Prescription}

\author{
Hubert Cheung ${ }^{1 \star t}$, Lorraine Mazerolle ${ }^{2 \dagger}$, Hugh P. Possingham ${ }^{1,3 \dagger}$ and Duan Biggs ${ }^{4,5,6 t}$ \\ ${ }^{1}$ Centre for Biodiversity and Conservation Science, School of Biological Sciences, The University of Queensland, Brisbane, \\ QLD, Australia, ${ }^{2} A R C$ Centre of Excellence for Children and Families Over the Life Course, School of Social Science, \\ University of Queensland, Brisbane, QLD, Australia, ${ }^{3}$ The Nature Conservancy, South Brisbane, QLD, Australia, \\ ${ }^{4}$ Environmental Futures Research Institute, Griffith University, Nathan, QLD, Australia, ${ }^{5}$ Department of Conservation Ecology \\ and Entomology, Stellenbosch University, Matieland, South Africa, ${ }^{6}$ Centre for Complex Systems in Transition, School of \\ Public Leadership, Stellenbosch University, Stellenbosch, South Africa
}

Despite the international ban on the trade of rhino horn that has been in place since 1977, persistent demand for horn in Asia has driven a spike in poaching over the past decade. This has embroiled the conservation community in a debate over the efficacy of banning trade relative to other solutions. Proposals for trade to be legalized and supplied through the dehorning of live rhinos or the production of synthetic horn are contentious. The need for empirical research into the potential impacts of legalization on demand was made more urgent in 2018 when China publicized its intentions to reopen its domestic trade and permit the use of rhino horn in medical treatment. In this study, we interviewed 84 Traditional Chinese Medicine (TCM) practitioners in the Chinese province of Guangdong. While $58(69.05 \%, n=84)$ of our interviewees were in favor of trade legalization, only $32(38.10 \%, n=84)$ thought it likely that trade legalization would cause them to increase their prescription of rhino horn over current levels. This is probably because clinical cases in which rhino horn is medically appropriate are uncommon. We also found that $33(39.29 \%, n=84)$ practitioners were open to using synthetic horn for patient treatment, which has implications for the viability of synthetic horn as a conservation tool. This research contributes empirical insight to advance the discourse on rhino horn trade policy.

Keywords: Chinese consumers, conservation policy, demand, medicinal use, poaching, rhino conservation, wildlife consumption, wildlife trade

\section{INTRODUCTION}

People and communities around the world consume wildlife products for diverse reasons (ThomasWalters et al., 2020), making wildlife trade a tremendously lucrative industry. For many taxa, trade is legal and sustainable. However, the survival of thousands of species, including iconic wildlifelike rhinos and elephants, is threatened by unsustainable levels of illegal wildlife trade (IWT) ('t Sas-Rolfes et al., 2019; Tittensor et al., 2020). To protect species against over-exploitation, the 
Convention on International Trade in Endangered Species of Wild Fauna and Flora (CITES) came into effect in 1975 to regulate international trade in the taxa listed on its appendices. International trade for commercial purposes is prohibited for species listed on Appendix I (Smith et al., 2011; Harfoot et al., 2018), and CITES signatories are expected to implement these trade controls and enact domestic legislation as appropriate ('t Sas-Rolfes et al., 2019).

The current approach to rhino conservation is centered on international and domestic trade controls. All extant species have been listed on Appendix I since 1977 (with the sole exception being the South African white rhino population's inclusion in Appendix II, for which international trade of live animals and of hunting trophies is conditionally permitted). However, poaching has risen substantially since 2007, and Africa's rhinos are projected to go extinct within the next 20 years under such intense poaching pressure (Di Minin et al., 2015). Rhino are poached for their horns because each kilogram can fetch USD \$30,000-60,000 on the black market (Eikelboom et al., 2020). The rise in poaching is attributed to growing wealth and demand in Asia, particularly China and Vietnam, where rhino horn is used in cultural, social and medicinal settings (Di Minin et al., 2015). Rhino horn is used as an ingredient in Traditional Chinese Medicine (TCM) pharmacotherapy (herbal decoctions for treating illness or promote health by restoring holistic balance), mainly to dispel heat, detoxify and cool the blood, and treat febrile diseases (Cheung et al., 2018a, 2020a). It is thought to impart potent "cold" properties, most appropriately used against heat that has been trapped deep within the body (But et al., 1990).

\section{Trade Legalization Debate}

Increased demand and poaching have raised skepticism over the effectiveness of trade bans (Conrad, 2012; Challender et al., 2019). Should high rates of poaching persist, tens of millions of dollars will be needed annually for rhino protection alone (Di Minin et al., 2015). Other conservation interventions have also been scrutinized. Increasingly militarized anti-poaching presents serious ethical concerns and risks alienating key stakeholders (Duffy et al., 2015). Recent research has also identified limitations to behavior change interventions aimed at lowering demand for animal-based TCM products in Asia (Moorhouse et al., 2020). These all point to the need for the conservation community to consider all available policy options.

Some conservationists have argued that permitting regulated trade of horn from the two African species of rhino can depress prices from their current black market levels and reduce financial incentives for illegal actors. Legal trade can also generate funds which can be invested in local community development and in strengthening security and protection for rhino (Biggs et al., 2013; Di Minin et al., 2015; Rubino and Pienaar, 2020). Rhino horn can supplied either through non-lethal, renewable harvest of horns from wild or farmed rhino (henceforth "harvested horn") (Lindsey and Taylor, 2011; Taylor et al., 2017) or through the mass production of bioengineered synthetics, which are being developed to be virtually indistinguishable from natural horn (henceforth "synthetic horn") (Chen, 2017; Mi et al., 2019).
However, other conservationists have raised concerns and pointed to uncertainties surrounding both supply and demand (Collins et al., 2013; Aguayo, 2014). In particular, how demand will respond to trade legalization is unknown. Legalization could lift stigma surrounding illicit consumption and expand demand at a time when the Chinese government is actively promoting TCM domestically and abroad (Haas and Ferreira, 2016; Eikelboom et al., 2020). The potential for poached horn to be laundered into legal stocks is a major concern, one which is exacerbated by persistent corruption along IWT routes (Smith et al., 2015; Wyatt et al., 2018; Eikelboom et al., 2020). There are also animal welfare concerns (Brown et al., 2019).

Views on the sustainable use of wildlife can be polarized (Hutton and Leader-Williams, 2003). As with the debate over the trade in ivory (Biggs et al., 2017), policymaking over legalizing the rhino horn trade has become similarly deadlocked. The proposals that several rhino range states have lodged for CITES to permit some international trade have all been rejected. These repeated rejections have led the Southern African Development Community to threaten outright withdrawal from the Convention, arguing that the restrictions imposed on their use of natural resources is unfair and driven by anti-sustainable use ideologies (Challender et al., 2015; CITES, 2019). Although international trade remains banned under CITES, some countries have moved unilaterally toward domestic legalization in recent years. In South Africa, home to the majority of the world's rhino, a 2015 high court decision lifted the national moratorium on domestic rhino horn trading (Collins et al., 2020). In 2018, China publicized its intentions to reopen its domestic rhino horn (and tiger bone) trade (People's Republic of China, 1993a, 2018b).

\section{China's Revised Policy on Domestic Rhino Horn Trade}

In 1993, China implemented several policies that shut down its domestic rhino horn trade. First, all CITES-listed taxa were added to the Directory on Special State Protection of Wildlife (People's Republic of China, 1993b), placing them under the scope of the Law on the Protection of Wildlife (People's Republic of China, 1989). The State Council further issued a circular to explicitly: (1) ban the import, export, sale, purchase, transport, carrying, and mailing of rhino horn; (2) abolish all rhino hornrelated medicinal standards and prohibit further medicinal use; (3) promote the use of rhino horn substitutes; and (4) mandate that all horn stocks be registered (People's Republic of China, 1993a).

However, this was revoked by the State Council in 2018. In a new circular, the Chinese government outlined nuanced parameters within which a legal domestic trade is to be reopened; activities beyond these parameters are to remain illegal (People's Republic of China, 2018b). The use of rhino horn is to be limited to clinical application in TCM, medical research, preserving antique cultural artifacts, and as educational materials.

Under the conditions set out in the circular, only powdered rhino horn sourced from captive bred animals (excluding zoo animals) is to be permitted for medicinal use. Clinical access is to be restricted to "qualified" doctors in "eligible" hospitals for 
the treatment of severe, critical, or rare illnesses; the criteria to determine which doctors are "qualified" and which hospitals are "eligible" is to be determined by the National Administration of TCM. To prevent misuse and abuse, measures related to the quantity, structure, and labeling of rhino horn supplies are to be jointly established by the National Forestry and Grassland Administration, Ministry of Industry and Information Technology and National Administration of TCM (People's Republic of China, 2018b).

The circular immediately drew widespread criticism from international conservation and animal welfare organizations (Humane Society International, 2018; UNEP, 2018; WWF Global, 2018), prompting the State Council's Executive Deputy Secretary-General to clarify that the issuance of the detailed regulations needed for implementation would be postponed, though the statement indicated that the Chinese government remains committed to reopening trade sooner or later (People's Republic of China, 2018a). As such, empirical insight into how demand in China is likely to respond is urgently needed to inform conservation decision-making. As of the publication of this paper, the Chinese domestic ban on rhino horn trade and medicinal use continues to be in force, though various challenges continue to hinder enforcement efforts (Li, 2007; Wong, 2019). These include porous borders and insufficient information sharing with neighboring countries, as well as the relatively light threat of prosecution for and alleged involvement of officials in wildlife crimes (Stephens and Southerland, 2018).

\section{Present Study}

In this paper, we focus on the views and perceptions of TCM practitioners and the potential impact of trade legalization on their behavioral intentions with respect to the prescription of rhino horn. TCM practitioners occupy a unique intermediary position in the IWT chain (Phelps et al., 2016). In China, TCM is practiced alongside and integrated with biomedicine (Western medicine) at every level of the healthcare system (Chen and Qian, 2019). TCM practitioners can both prescribe and dispense medication to patients (Sun et al., 2008; Fang et al., 2013; Zhang et al., 2015), and so their use of medicinal ingredients like rhino horn affects both supply and demand-prescribing contributes to overall demand, dispensing provides retail supply.

Once domestic trade is reopened, the 2018 circular stipulates that "qualified" TCM practitioners will be granted access to rhino horn powder obtained from captive-bred animals for patient treatment (People's Republic of China, 2018b). However, the postponed issuance of regulatory details means that a number of critical questions are unanswerable at present (People's Republic of China, 2018a). The specifics surrounding access are unclear. What will qualify a practitioner for access to rhino horn? Which medical conditions or illnesses will warrant its use? The circular also makes no mention of synthetic horn. Whether its pharmaceutical use would be permitted or restricted is unknown, as is whether these products would even be considered rhino horn in legal terms (and thus be subject to the same regulations as natural horn).

Although the specifics of China's eventual reopening of trade remain unknown, empirical research will provide conservationists insight with which to evaluate the potential opportunities and risks associated with trade legalization in China and internationally. In this study, we conducted semi-structured interviews with TCM practitioners in China's Guangdong province. We focused on four questions:

1. What are the perspectives of TCM practitioners with regards to the present ban on the trade and medicinal use of rhino horn?

2. Do TCM practitioners support or oppose trade legalization for harvested rhino horn? For synthetic horn?

3. How likely are TCM practitioners to increase or decrease their prescriptions of rhino horn over present levels if harvested horn is legally available? If synthetic horn is legally available?

4. What demographic and professional characteristics predict changes to rhino horn prescription in terms of behavioral intentions if harvested horn is legally available? If synthetic horn is legally available?

\section{METHODS}

\section{Study Area}

Guangdong province is located on the southeastern coast of China. It is the largest Chinese province by population $(108,490,000$ in 2015) and is one of the wealthiest (household per capita disposable income $\sim$ USD $\$ 4,170$ and per capita GDP $\sim$ USD $\$ 10,900$ in 2015) (National Bureau of Statistics of China, 2016). In the provincial capital of Guangzhou, rates of wildlife consumption as food and for medicinal purposes is higher than other large cities in China--31.2\% of people in Guangzhou consume TCM or health products containing wildlife ingredients annually, compared with $1.5 \%$ and $2.8 \%$ in Beijing and Shanghai respectively (Zhang and Yin, 2014).

TCM practitioners most commonly prescribe rhino horn for dispelling heat, detoxifying the blood, and treating wenbing (Chinese in Traditional script/Simplified script/pinyin: 温病/温 病/wèn bing; warm-heat infectious diseases) (Cheung et al., 2018a). These include such diseases as SARS and COVID19, both of which are considered wenyi (温病/温病/wèn yi; epidemics of wenbing) (Liu and Wang, 2020). Wenbing is most associated with acute infections and epidemics in southern China (Hanson, 2011).Taken together, these factors suggest that rhino horn is likely to be more affordable to and more widely used by Guangdong's residents of Guangdong than in other parts of the country, making it an appropriate focal point for our study.

\section{Interview Methodology}

We conducted semi-structured interviews face-to-face with 84 TCM practitioners in Guangdong province between 29th July and 14th November 2018 (excluding two interviewees who withdrew participatory consent; see Supplementary Materials for explanation). Semi-structured interviews are used extensively in environmental studies. A set of key questions is used to guide each interview (see Supplementary Materials for key questions), and interviewers follow up with additional questions and encourage elaboration to enhance data with nuance and context (Newing, 2011). Responses to questions regarding TCM 
practitioners' support of or opposition to trade legalization, and those regarding the likelihood that they would increase or decrease rates of prescription over current levels, were recorded using 5-point Likert scales. The research methodology we employed here built on a previous study in which we interviewed TCM practitioners in Hong Kong on the subject of rhino horn use (Cheung et al., 2018a). For the present study, we pilot tested our study instrument with 30 TCM practitioners in Hong Kong to improve the focus of our key questions, including refining our translated measures for connectedness-to-nature and formal deterrence (Cheung et al., 2020b).

We employed a broad definition of TCM practitioner for participant recruitment: any self-identified (licensed, qualified, or otherwise) physician who provides to members of the public TCM services (inpatient or outpatient; prescribes treatment). By using such broad criteria, we could recruit unlicensed individuals and herbalist shopkeepers who offer medical consultations and prescribe herbal decoctions in addition to physicians working in larger institutions (e.g., hospitals) (Li et al., 2017).

Our broad recruitment criteria meant that we were unable to sample randomly from the population, as the total population could not be determined as there was no official listing of all practitioners in the region. Instead, we recruited study participants using snowball sampling, an established method for studying sensitive topics (Heckathorn, 2011; Newing, 2011). We started with a core convenience group of 35 participants, who were recruited through personal contacts and acquaintances made through earlier work. A further 23 interviewees were approached initially through self-introduction. All interviewees were asked to refer fellow TCM practitioners to participate in our research; 26 interviews done through referrals. Studies of illegal tiger and ivory trading in China have used similar sampling methodologies that involved participant referrals (Wong, 2016, 2017). While such approaches to participant recruitment can make it easier to access populations that are difficult to study, they can incur methodological limitations and biases for study results.

The vast majority of interviews were conducted at the participant's primary workplace (e.g., hospital, clinic, and herbal medicine shop). The average duration of each interview was $45 \mathrm{~min}$. We conducted 62 interviews before and 22 interviews after the State Council's circular to reopen domestic rhino horn trade was issued on 29th October 2018 (People's Republic of China, 2018b). Of the latter 22, only one interviewee had seen a news article on the subject and three others had seen related social media posts, none of whom were aware of any policy details. The remaining 18 had no knowledge of the circular. No interviewees had yet discussed the reopening of trade with colleagues. As such, any effects that the circular's release during our data collection period had on our results are most likely negligible. The demographic and professional characteristics of our sample are summarized in Table $\mathbf{1 .}$

\section{Data Analysis}

We used descriptive statistics to examine perspectives on the current ban on rhino horn trade and medicinal use, as well as support or opposition to trade legalization, both for a legal trade supplied through the de-horning of live rhino and through the mass production of bioengineered synthetics. Descriptive statistics were also used to examine the perceived likelihood of increasing prescriptions of rhino horn over current levels if a legal trade is supplied through the de-horning of live rhino and through the mass production of bioengineered synthetics. We then conducted hierarchical multiple regressions for the perceived likelihood of increasing rhino horn prescriptions over current levels of use in different legal trade scenarios. Demographic and professional covariates were entered into the model in the first step, before the effects of two theoretical constructs (deterrence and connectedness to nature; see Supplementary Materials for a discussion of these constructs) and past prescription of rhino horn were included in step two. R (version 3.6.1) was used for these regressions.

Trade restrictions lie at the center of the current approach to rhino conservation. The success of both international and domestic trade controls hinges on how compliant stakeholders along the IWT market chain are (Arias, 2015; Phelps et al., 2016; Oyanedel et al., 2020). Sanctions imposed for regulatory violation are a formal deterrence measure (Grasmick and Bursik, 1990). Deterrence is an established concept in criminology, whereby effectiveness is dependent on three central pillars: certainty, severity and celerity. Deterrence (and regulatory compliance) can be increased by manipulating these three elements (Nagin, 2013). In essence, compliance with potential offenders must perceive that the risk of being apprehended is high, that the punishment is sufficiently severe, and that sanctions will be imposed without delay.

A major point of contention in the rhino horn trade policy debate is whether legalization would lead to increased demand. In the case of TCM practitioners, this would be through the increased prescription of rhino horn once legalized. Here, we measured the formal deterrence of legal sanctions on rhino horn prescription using a composite scale adapted from criminological research (Grasmick and Bursik, 1990; Allen et al., 2017). We included this construct in our hierarchical multiple regressions to investigate the effect of perceived deterrence on TCM practitioners' likelihood of increasing prescriptions of rhino horn if harvested horn and synthetic horn are legalized.

Although strong compliance and enforcement programs are necessary for regulatory measures to control environmental behaviors and deter violations, "regulation cannot by itself produce the behavioral changes needed to achieve sustainable environmental outcomes" (Paddock, 2012), and drivers of compliance that are values-based drivers are also needed (Challender and Macmillan, 2014). Normative motivations are driven by a person's moral duty and agreement with the importance of a given regulation. These are based on internalized values which lend legitimacy to regulations, and people with a stronger sense of duty to adhere to a certain rule can be expected to comply at greater rates (Burby and Paterson, 1993; Winter and May, 2001).

People with pro-environmental attitudes are more likely comply with environmental regulations (Paddock, 2012). The connectedness-to-nature scale (Mayer and Frantz, 2004) and other similar measures have been developed around the idea that reconnecting people to nature can foster positive ecological 
TABLE 1 | Demographic characteristics of our sample of TCM practitioners.

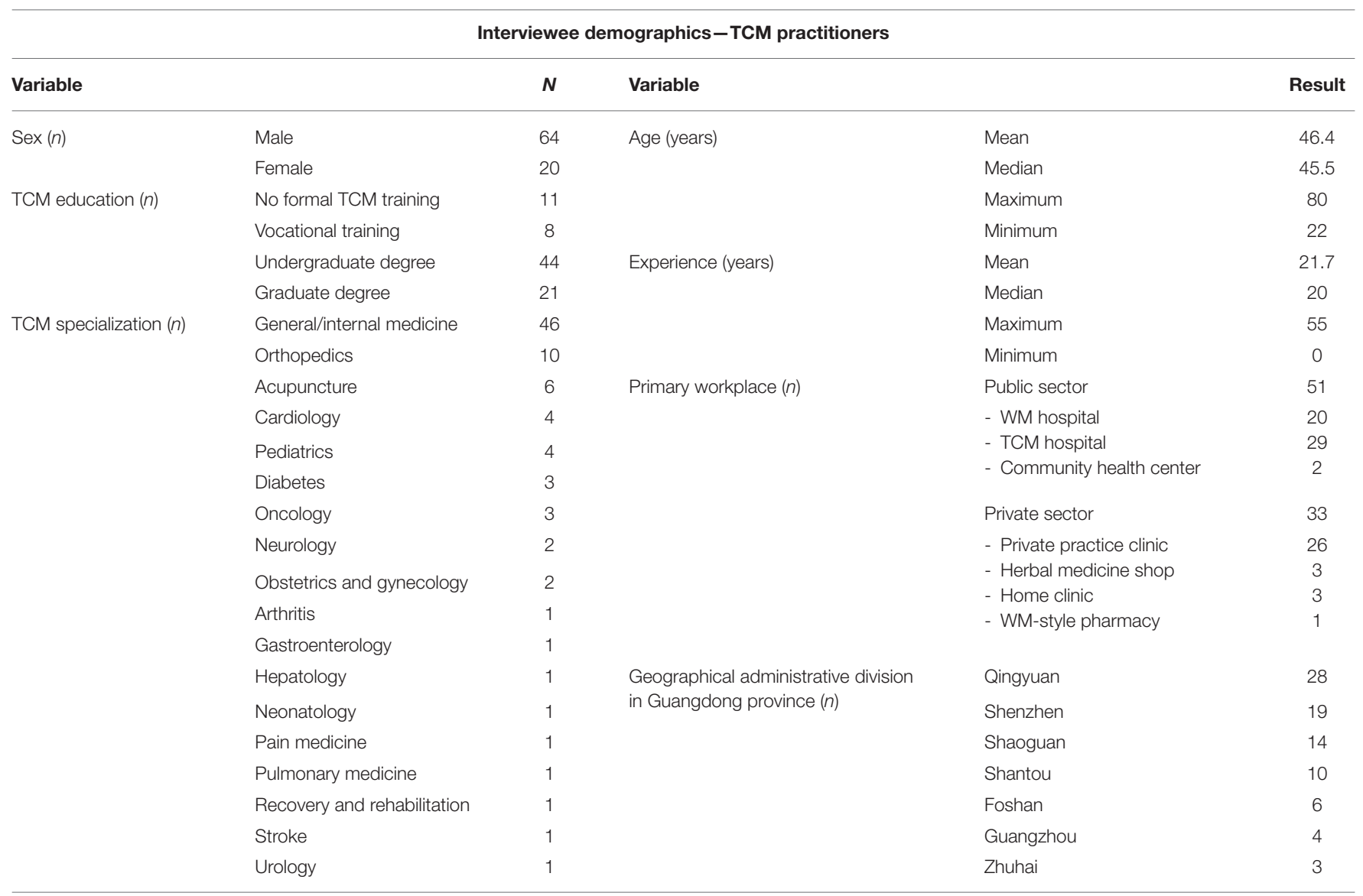

behavior and reduce anti-ecological behavior (Tam, 2013). In this study, we administered a Chinese version of the connectednessto-nature scale (Cheung et al., 2020b) to investigate its effect on the likelihood of TCM practitioners increasing prescriptions of rhino horn if harvested horn and synthetic horn are legalized.

\section{Research Ethics}

We complied with the Australian National Health and Medical Research Council's National Statement on Ethical Conduct in Human Research; institutional approval was granted by The University of Queensland (\#2017002130).

\section{RESULTS}

We found that $40(47.62 \%$, all $n=84)$ interviewees were supportive of the existing ban on trade and medicinal use, while $28(33.33 \%)$ interviewees were indifferent and accepting of this policy. Fifty-eight $(69.05 \%)$ felt that the ban has had minimal or no negative impact on TCM's development. Two $(2.38 \%)$ interviewees felt that the ban has had a major negative impact on TCM's development, while 20 (23.81\%) others reported some negative impact. Three (3.57\%) interviewees found the ban to be beneficial for TCM because it has encouraged innovation in the development of other treatments.
Fifty-eight $(69.05 \%)$ interviewees were in favor of proposals to legalize trade in harvested rhino horn, with 13 opposed (15.48\%) (Figure 1A). Thirty (35.71\%) interviewees described the legalization of trade in harvested horn as a win-win situation: patients can receive the treatment they need, and rhinos do not have to be killed in order to for their horns to be obtained. Ten $(11.90 \%)$ interviewees expressed views that mechanisms to regulate and certify supplies must be established and enforced to ensure the sustainability of such a trade. Eight (9.52\%) interviewees expressed animal welfare concerns over dehorning.

However, even if harvested horn were to be legally traded, our interviewees were split between those who found it unlikely that they would increase their prescription of rhino horn over current levels if trade were legalized $(n=45,53.57 \%)$ and those who predicted that they would increase their use of rhino horn $(n=$ 32, 38.10\%) (Figure 1B). When asked to elaborate, 39 (46.43\%) interviewees explained that they would be unlikely to prescribe rhino horn even if trade were legalized because cases where it is suitable for patient treatment are infrequent or rare. Seven $(8.33 \%)$ further stated that patients whose conditions severe enough to warrant treatment using rhino horn would have either been hospitalized for treatment using biomedicine or opted for it themselves. Four (4.76\%) interviewees cited personal ethics as the reason they would never prescribe rhino horn, even if it 


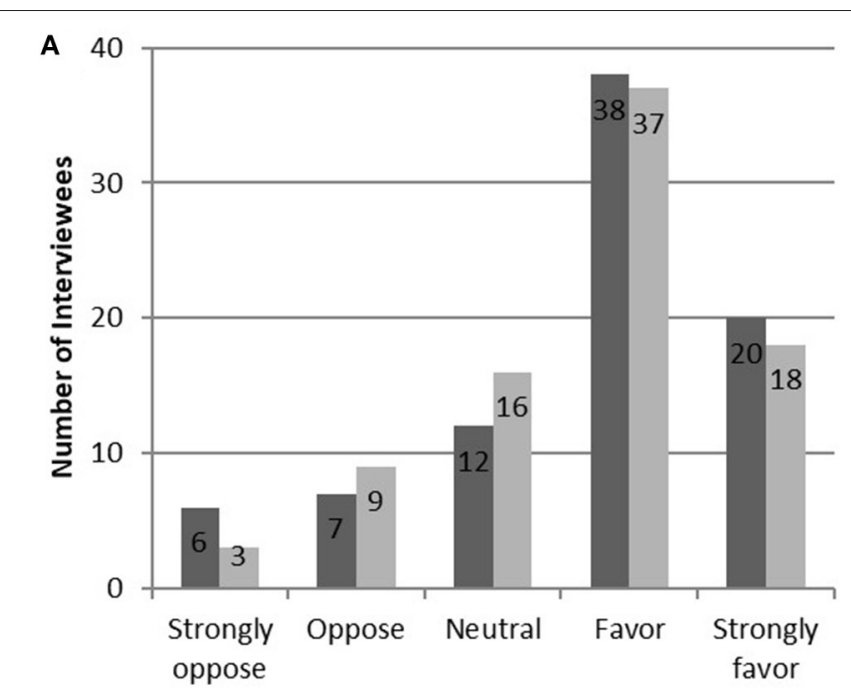

Support/opposition to trade legalization

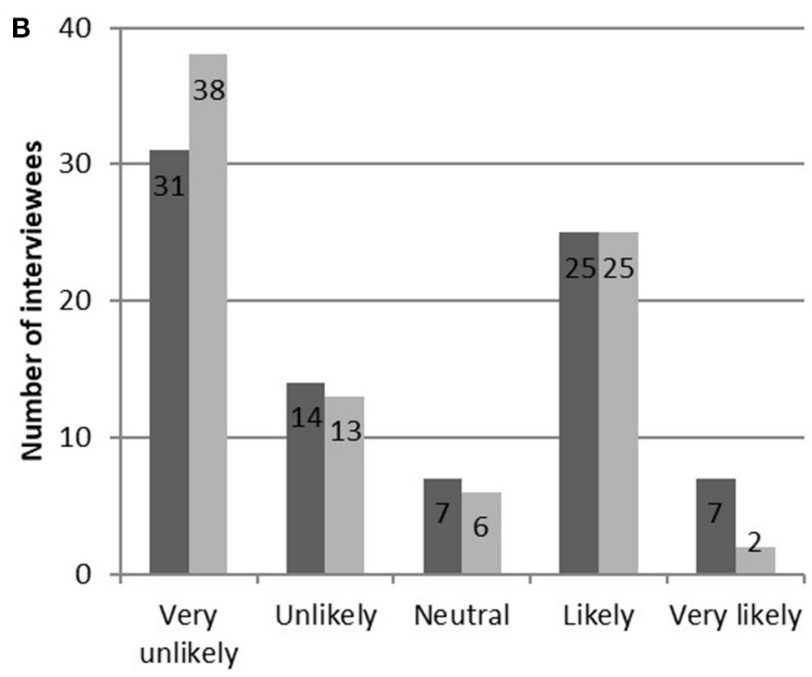

Likelihood of increased prescription

- Harvest by dehorning

Bioengineered synthetics

FIGURE 1 | TCM practitioners' (A) support for the legalization of trade in rhino horn supplied with harvested horn and synthetic horn; and (B) likelihood of increasing prescriptions of rhino horn from current levels if rhino horn were to be legally supplied with harvested horn and synthetic horn.

were legally available. A hierarchical multiple regression did not reveal any variables measured in our study (demographic factors, professional characteristics, connectedness to nature, feelings of shame, and deterrence) to have any statistically significant predictability with regards to the likelihood of increasing use over current levels if trade in harvested horn is legalized (Table 2A).

Fifty-three $(63.10 \%)$ practitioners also supported the idea of a legal trade in synthetic horn; only 12 (2.38\%) were opposed (Figure 1A). Fifty-one (60.71\%) interviewees reported that they would be unlikely to increase prescriptions of rhino horn over current levels if synthetic horn were legalized (more than for harvested horn), with $27(32.14 \%)$ predicting that they would be likely to do so (fewer than for harvested horn) (Figure 1B). Interviewees raised concerns over the pharmaceutical effectiveness and safety of consuming something synthetic, with 12 (14.29\%) interviewees stating that under no circumstances would they ever consider prescribing synthetic or artificially manufactured medicinal ingredients to their patients. Eleven $(13.10 \%)$ were of the opinion that a synthetic product simply cannot be made to be equivalent to "natural" rhino horn. Twelve (14.29\%) interviewees stated that ample testing would be needed to assure them that synthetic products are safe and effective for treatment before they would consider using it, and 33 (39.29\%) stated that they would only consider synthetic horn if it was shown to have equivalent or comparable clinical effectiveness to natural horn. A hierarchical multiple regression found that none of the variables we measured (demographic factors, professional characteristics, connectedness to nature, feelings of shame, and deterrence) were statistically significant with regards to likelihood of increasing rates of rhino horn prescription over current levels if trade in synthetic horn is legalized (Table 2B).

\section{DISCUSSION}

The increase in rhino poaching over the last decade and a half has called the efficacy of existing trade controls into question, and has stimulated a heated debate over policy alternatives like trade legalization (Biggs et al., 2013; Dang et al., 2020). The need for a better understanding of demand in China was made more urgent when the State Council issued its 2018 circular announcing that its domestic rhino horn trade is to be reopened (Cheung et al., 2018b). In this study, we conducted semi-structured interviews with $84 \mathrm{TCM}$ practitioners in the southeastern Chinese province of Guangdong. We found that almost half of our interviewees were supportive of the current ban on the trade and medicinal use of rhino horn; however, we also found that the majority of TCM practitioners favor legalizing rhino horn if it were to be sourced through the dehorning of live rhinos and the production of synthetic horn (Figure 1). This apparent conflict in support among TCM practitioners for contrasting trade policies is likely the result of a general lack of awareness that rhino horn grows continuously throughout a rhino's lifespan and can be considered, at least theoretically, a renewable resource. The majority of our interviewees suggested that they are unlikely to increase their prescription of rhino horn over current levels even if its trade and medicinal use were to be legalized. This sentiment was more pronounced for synthetic horn than for harvested horn, largely due to concerns over pharmaceutical effectiveness and safety, as well as ethical opposition to the use of artificial medicinal ingredients. In contrast, supplying a legal trade with harvested horn was described by a third of our interviewees as 
TABLE 2 | Hierarchical multiple regression for the effect of demographic factors, connectedness to nature, shame, and deterrence on TCM practitioners' likelihood of increasing prescriptions of rhino horn if (A) harvested horn is legalized, and (B) synthetic horn is legalized.

\begin{tabular}{|c|c|c|c|c|c|c|c|c|}
\hline \multicolumn{9}{|c|}{ (A) Likelihood of increasing prescriptions if harvested horn is legalized } \\
\hline \multirow[t]{2}{*}{ Variable } & \multicolumn{4}{|c|}{ Model 1} & \multicolumn{4}{|c|}{ Model 2} \\
\hline & $B$ & SE & $\beta$ & $p$ & $B$ & SE & $\beta$ & $p$ \\
\hline Constant & 2.605 & 1.669 & & 0.123 & 1.964 & 2.338 & & 0.404 \\
\hline Age & -0.010 & 0.033 & -0.293 & 0.770 & -0.012 & 0.034 & -0.357 & 0.722 \\
\hline Gender (M/F) & -0.253 & 0.401 & -0.631 & 0.530 & -0.238 & 0.405 & -0.587 & 0.559 \\
\hline Education & 0.318 & 0.226 & 1.411 & 0.162 & 0.309 & 0.234 & 1.318 & 0.192 \\
\hline Experience & 0.013 & 0.030 & 0.424 & 0.673 & 0.011 & 0.031 & 0.342 & 0.734 \\
\hline Workplace sector (public/private) & -0.346 & 0.385 & -0.898 & 0.372 & -0.358 & 0.390 & -0.920 & 0.361 \\
\hline Connectedness to nature & & & & & 0.017 & 0.475 & 0.037 & 0.971 \\
\hline Formal deterrence (legal sanctions) & & & & & 0.175 & 0.228 & 0.767 & 0.445 \\
\hline Prescribed rhino horn in the past & & & & & 0.398 & 0.394 & 1.011 & 0.315 \\
\hline$R^{2}$ & & & & 0.065 & & & & 0.082 \\
\hline Adjusted $R^{2}$ & & & & 0.005 & & & & -0.016 \\
\hline$\Delta R^{2}$ & & & & & & & & +0.017 \\
\hline$\Delta F$ & & & & 1.075 & & & & 0.836 \\
\hline Df & & & & $5(78)$ & & & & $8(75)$ \\
\hline$p$-value & & & & 0.381 & & & & 0.574 \\
\hline \multicolumn{9}{|c|}{ (B) Likelihood of increasing prescriptions if synthetic horn is legalized } \\
\hline Constant & 1.974 & 1.601 & & 0.221 & 0.374 & 2.214 & & 0.866 \\
\hline Age & -0.002 & 0.032 & -0.058 & 0.954 & -0.008 & 0.032 & -0.235 & 0.815 \\
\hline Gender (M/F) & 0.056 & 0.385 & 0.147 & 0.884 & 0.072 & 0.384 & 0.188 & 0.852 \\
\hline Education & 0.177 & 0.217 & 0.819 & 0.415 & 0.139 & 0.222 & 0.629 & 0.532 \\
\hline Experience & -0.002 & 0.029 & -0.076 & 0.940 & -0.002 & 0.029 & -0.072 & 0.943 \\
\hline Workplace sector (public/private) & -0.099 & 0.369 & -0.268 & 0.790 & -0.103 & 0.369 & -0.279 & 0.781 \\
\hline Connectedness to nature & & & & & 0.170 & 0.450 & 0.378 & 0.707 \\
\hline Formal deterrence (legal sanctions) & & & & & 0.320 & 0.216 & 1.479 & 0.143 \\
\hline Prescribed rhino horn in the past & & & & & 0.398 & 0.373 & 1.067 & 0.290 \\
\hline$R^{2}$ & & & & 0.031 & & & & 0.073 \\
\hline Adjusted $R^{2}$ & & & & -0.031 & & & & -0.026 \\
\hline$\Delta R^{2}$ & & & & & & & & +0.042 \\
\hline$\Delta F$ & & & & 0.496 & & & & 0.736 \\
\hline Df & & & & $5(78)$ & & & & $8(75)$ \\
\hline$p$-value & & & & 0.779 & & & & 0.660 \\
\hline
\end{tabular}

a win-win solution, whereby rhinos do not need to be killed for patients to receive the treatment they require.

Some conservationists and rhino range states see trade legalization as a potential way to reduce prices from their current black market levels, disincentivize poaching, and provide a renewable source of income to fund protection and enforcement (Biggs et al., 2013; Rubino and Pienaar, 2020). This remains controversial, and many other conservationists, range states, and international organizations have opposed such calls, concerned that legalization would increase demand and exacerbate poaching (Haas and Ferreira, 2016; WWF Global, 2018; Eikelboom et al., 2020). Although differences in entrenched values have led to a deadlock (Biggs et al., 2017; CITES, 2019), conservationists across the board agree on the need for policy to be informed with evidence and research (Gao et al., 2016; Haas and Ferreira, 2016; Wright et al., 2016; Chen, 2017; Hanley et al., 2018).
Understanding how TCM practitioners and consumers-who are major stakeholders in the global marketplace for rhino hornare likely to respond to trade legalization is important because any shifts in demand will directly affect the success of rhino conservation (Cheung et al., 2018a). The State Council's 2018 circular stipulated that rhino horn powder will be accessible to "qualified" doctors in "eligible" hospitals for limited use in TCM for patient treatment. Horn powder used for medicinal purposes will need to be obtained from captive bred animals (excluding zoo animals), though precisely how this would be sourced was not stated (People's Republic of China, 2018b). Although the implementation of the new policy has since been suspended, it amplified the urgency of gaining insight into the medicinal demand for rhino horn. Our study represents the first investigation of how TCM practitioners in China would potentially respond to domestic trade legalization. 


\section{Policy Implications}

In its 2018 circular reopening its domestic rhino horn trade, the Chinese government indicated clearly that a legal trade will be subject to certain regulatory measures to be established by the relevant authorities (People's Republic of China, 2018b). This was reiterated in the clarification given by the State Council's Executive Deputy Secretary-General Ding Xuedong that implementation will be postponed, in which he maintained that "the circular should be implemented based on its detailed regulations for implementation"(People's Republic of China, 2018a). Our findings are particularly noteworthy in the context of the parameters outlined in the State Council's 2018 circular. In particular, the circular stipulates that medical access to rhino horn powder is to be restricted to "clinical use for the treatment of serious or critical conditions and rare illnesses that are otherwise difficult to cure” (床救治危急重症、疑症临床救治危 急重症、疑难杂症/lín chuáng jiù zhi wéi jí zhòng zhèng, yí nán zá zhèng) (People's Republic of China, 2018b). Our findings appear to be consistent with this description, albeit on a coarse scale given that details of the specific conditions for which rhino horn can be accessed for medical use have yet to be established (or if they have been established, have yet to be announced) by the relevant government agencies as stipulated in the 2018 circular.

Around half of our interviewees stated that they are unlikely to prescribe rhino horn (whether harvested or synthetic) even if its use and trade were legalized. They described opportunities to use rhino horn as being rare, because patient cases in which its application is appropriate are uncommon. Previous exploratory research that focused on TCM practitioners in Hong Kong revealed similar trends and perspectives (Cheung et al., 2018a). The rarity of patient cases in which rhino horn is an appropriate (let alone necessary) treatment appears to be consistent with the parameters for medicinal use laid out in the 2018 circular. Our results indicate that conservationists should take into account the perceived rarity of clinical cases for which rhino horn is appropriate when assessing concerns that the removal of stigma associated with trade legalization will cause demand to increase, at least with regards to clinical use by TCM practitioners.

Our findings also provide insight into the potential viability of synthetic rhino horn as a conservation tool. These are being developed by several biotechnology firms (Mi et al., 2019) under the premise that: (a) "flooding the market with [synthetic horn] reduces the price, thereby (it is theorized), reducing the levels of poaching" (Crookes, 2017); and (b) "if synthetic horns that are biologically identical (bio-identical) to the real thing can be produced at a lower cost compared to the cost of supplying wild horns, the demand for wild horns would decrease as buyers shift consumption toward the synthetic products" (Chen, 2017). With rhino horn demand understood to be relatively price-inelastic in nature, recent economic modeling by Chen and 't Sas-Rolfes (2021) found that establishing a legal market for synthetic horn is likely to reduce poaching.

Concerns have been raised that introducing synthetic horn to the market may not reduce the supply of natural horn or disincentivize poaching if users are able to differentiate between them and perceive synthetic horn to be an inferior product (Chen, 2017). Indeed, our results show that many TCM practitioners would perceive synthetic rhino horn to be less desirable than natural horn. One in seven of our interviewees would never consider synthetic medicinal ingredients for patient treatment. On the other hand, it is encouraging that a substantial portion of TCM practitioners is open to the idea of using synthetic products for patient treatment and that perceptions of synthetic horn in relation to natural horn are not homogenous. We found that two in five TCM practitioners would consider using synthetic horn (if legally available and with the knowledge that it is a synthetic product) for patient treatment if its clinical effectiveness is shown to be equivalent or comparable to that of natural horn (n.b. we stress that evidence for the pharmaceutical efficacy of rhino horn in biomedical terms is limited and questionable at best). This has implications for the development of synthetic horn and its deployment as a conservation tool once domestic trade in China is reopened. If the pharmaceutical efficacy of synthetic horn can indeed be demonstrated, then a substantial portion of medicinal demand could be satisfied with synthetic products without great opposition from TCM practitioners.

\section{Limitations and Future Research}

In the present study, we were unable to identify any variables that could predict TCM practitioners' self-reported likelihood of increasing their rhino horn prescription rate if trade in harvested or synthetic horn were to be legalized (Table 2). Recognizing that the goodness-of-fit for the two relevant regressions were poor and noting the limitations of our sampling methods, we posit that a substantial amount of variance is attributable to the rarity of situations in which rhino horn is medically appropriate. Additional research may be able to provide further insight into other factors at play that can predict potential changes in rhino horn prescription rates which were not measured in the present study.

We stress the methodological limitations of our results. This study focused on self-identified TCM practitioners in Guangdong province. Our findings should not be interpreted as nationally representative because TCM practices and norms, socioeconomics, healthcare access vary across different regions of China (Ling et al., 2011; Li et al., 2018). Our study focused on perceptions and behavioral intentions, which may not reflect the actual behaviors that TCM practitioners will ultimately take upon the legalization of domestic trade (Ajzen, 1991; Sheeran and Webb, 2016). The broad inclusion criteria we employed for participant recruitment had both benefits and drawbacks. By reaching active practitioners who are not licensed or trained, we were able to gauge sentiments regarding the current trade ban and trade legalization from a wider group. However, this prevented us from sampling randomly from the total population of TCM practitioners.

The 2018 circular to reopen domestic trade was issued toward the end of our data collection period, and we were 
unable to adapt our study in response to the circular's issuance. Studies in the future should aim to provide more focused insight with regards to the stated parameters of China's trade legalization plans. For instance, future research involving TCM practitioners in China should concentrate specifically on individuals who work in hospitals. While the development status of the regulatory details necessary for the circular's implementation is unknown, the Chinese government's intention to reopen domestic trade sooner or later is unlikely to have wavered. It may be prudent for conservationists to engage with the relevant Chinese agencies tasked with establishing these regulatory details and implementation measures in order to be a part of that process to manage the risks to wildlife.

\section{DATA AVAILABILITY STATEMENT}

Due to the possible sensitivity of human subjects' data and in compliance with human research ethics approval granted by University of Queensland, survey data are only accessible to the authors. However, anonymized data may be accessible by request on an individual basis.

\section{ETHICS STATEMENT}

We complied with the Australian National Health and Medical Research Council's National Statement on Ethical Conduct in Human Research; institutional approval was granted by The University of Queensland (\#2017002130). Written informed consent for participation was not required for this study in

\section{REFERENCES}

Aguayo, F. (2014). "Rhino horn and the economics of of wildlife trade: risks and uncertainties," in Assessing the Risks of Rhino Horn Trade: A Journal of Arguments Presented at the April 2014 Conference in South Africa (Mozambique), 25-29.

Ajzen, I. (1991). The theory of planned behavior. Organ. Behav. Hum. Decis. Process. 50, 179-211. doi: 10.1016/0749-5978(91)90020-T

Allen, S., Murphy, K., and Bates, L. (2017). What drives compliance? The effect of deterrence and shame emotions on young drivers' compliance with road laws. Policy Soc. 27, 884-898. doi: 10.1080/10439463.2015.11 15502

Arias, A. (2015). Understanding and managing compliance in the nature conservation context. J. Environ. Manage. 153, 134-143. doi: 10.1016/j.jenvman.2015.02.013

Biggs, D., Courchamp, F., Martin, R., and Possingham, H. (2013). Legal trade of Africa's rhino horns. Science 339, 1038-1039. doi: 10.1126/science.12 29998

Biggs, D., Holden, M. H., Braczkowski, A., Cook, C. N., Milner-Gulland, E. J., Phelps, J., et al. (2017). Breaking the deadlock on ivory. Science 358, 1378-1381. doi: 10.1126/science.aan5215

Brown, A. A., Dean, A. J., Possingham, H., and Biggs, D. (2019). The role of animal welfare values in the rhino horn trade debate. Conserv. Sci. Pract. 1:e103. doi: $10.1111 / \operatorname{csp} 2.104$

Burby, R. J., and Paterson, R. G. (1993). Improving compliance with state environmental regulations. J. Policy Anal. Manage. 12, 753-772. doi: $10.2307 / 3325349$ accordance with national legislation and institutional requirements.

\section{AUTHOR CONTRIBUTIONS}

HC conceived and designed the study, conducted the interviews, analyzed the results, and wrote the manuscript. LM, HP, and DB contributed to the design of the study, to the statistical analysis, and to the text of the manuscript. All authors approved the final manuscript for submission.

\section{FUNDING}

HC received scholarship and research funding from the Lee Shau Kee Foundation. DB is supported by an Australian Research Council Discovery Early Career Research Grant (DE 160101182).

\section{ACKNOWLEDGMENTS}

HC is very grateful to the Lee Shau Kee Foundation for their provision of scholarship and research funding for this project. DB is supported by an Australian Research Council Discovery Early Career Research Grant (DE 160101182). We are grateful to those who helped us over the course of this project, in particular LKY, $\mathrm{XJK}$, and the individuals who connected us with stakeholders in the TCM community.

\section{SUPPLEMENTARY MATERIAL}

The Supplementary Material for this article can be found online at: https://www.frontiersin.org/articles/10.3389/fevo. 2021.607660/full\#supplementary-material

But, P. P.-H., Lung, L.-C., and Tam, Y.-K. (1990). Ethnopharmacology of rhinoceros horn. I: Antipyretic effects of rhinoceros horn and other animal horns. J. Ethnopharmacol. 30, 157-168. doi: 10.1016/0378-8741(90)90005-E

Challender, D. W., Hinsley, A., and Milner-Gulland, E. (2019). Inadequacies in establishing CITES trade bans. Front. Ecol. Environ. 17, 199-200. doi: $10.1002 /$ fee. 2034

Challender, D. W. S., Harrop, S. R., and Macmillan, D. C. (2015). Towards informed and multi-faceted wildlife trade interventions. Glob. Ecol. Conserv. 3, 129-148. doi: 10.1016/j.gecco.2014.11.010

Challender, D. W. S., and Macmillan, D. C. (2014). Poaching is more than an enforcement problem. Conserv. Lett. 7, 484-494. doi: 10.1111/conl.12082

Chen, F. (2017). The economics of synthetic rhino horns. Ecol. Econ. 141, 180-189. doi: 10.1016/j.ecolecon.2017.06.003

Chen, F., and 't Sas-Rolfes, M. (2021). Theoretical analysis of a simple permit system for selling synthetic wildlife goods. Ecol. Econ. 180:106873. doi: 10.1016/j.ecolecon.2020.106873

Chen, X., and Qian, X. (2019). “Overview of healthcare system in China,” in Quality Spine Care: Healthcare Systems, Quality Reporting, and Risk Adjustment, eds. J. Ratliff, T. J. Albert, J. Cheng, and J. Knightly (Cham: Springer International Publishing), 237-254. doi: 10.1007/978-3-319-97990-8_15

Cheung, H., Doughty, H., Hinsley, A., Hsu, E., Lee, T. M., Milner-Gulland, E. J., et al. (2020a). Understanding traditional Chinese medicine to strengthen conservation outcomes. People Nat. doi: 10.1002/pan3.10166

Cheung, H., Mazerolle, L., Possingham, H. P., and Biggs, D. (2018a). Medicinal use and legalized trade of rhinoceros horn from the perspective of traditional Chinese medicine practitioners in Hong Kong. Trop. Conserv. Sci. 11, 1-8. doi: $10.1177 / 1940082918787428$ 
Cheung, H., Mazerolle, L., Possingham, H. P., Tam, K.-P., and Biggs, D. (2020b). A methodological guide for translating study instruments in cross-cultural research: adapting the 'connectedness to nature' scale into Chinese. Methods Ecol. Evol. 11, 1379-1387. doi: 10.1111/2041-210X.13465

Cheung, H., Wang, Y., and Biggs, D. (2018b). China's reopened rhino horn trade. Science 362, 1369-1369. doi: 10.1126/science.aav9392

CITES (2019). "Summary record of the fourth plenary session-Eighteenth meeting of the Conference of the Parties, Convention on International Trade in Endangered Species of Wild Fauna and Flora," in Convention on International Trade in Endangered Species of Wild Fauna and Flora. (Geneva). Available online at: https://cites.org/sites/default/files/eng/cop/18/Plen/SR/ECoP18-Plen-Rec-04-R1.pdf

Collins, A., Cox, C., and Marire, J. (2020). On the judicial annulment of the 'domestic' trade moratorium in South African rhinoceros horn: a law and economics perspective. Eur. J. Law Econ. 49, 361-372. doi: 10.1007/s10657-020-09648-4

Collins, A., Fraser, G., and Snowball, J. (2013). Rhino poaching: Supply and demand uncertain. Science 340, 1167. doi: 10.1126/science.340.6137.1167-a

Conrad, K. (2012). Trade bans: a perfect storm for poaching? Trop. Conserv. Sci. 5 , 245-254. doi: 10.1177/194008291200500302

Crookes, D. J. (2017). Does a reduction in the price of rhino horn prevent poaching? J. Nat. Conserv. 39, 73-82. doi: 10.1016/j.jnc.2017.07.008

Dang, V. H. N., Nielsen, M. R., and Jacobsen, J. B. (2020). Reference group influences and campaign exposure effects on rhino horn demand: qualitative insights from Vietnam. People Nat. 2, 932-939. doi: 10.1002/pan3.10121

Di Minin, E., Laitila, J., Montesino-Pouzols, F., Leader-Williams, N., Slotow, R., Goodman, P. S., et al. (2015). Identification of policies for a sustainable legal trade in rhinoceros horn based on population projection and socioeconomic models. Conserv. Biol. 29, 545-555. doi: 10.1111/cobi.12412

Duffy, R., St John, F. A., Büscher, B., and Brockington, D. (2015). The militarization of anti-poaching: undermining long term goals? Environ. Conserv. 42, 345-348. doi: $10.1017 /$ S0376892915000119

Eikelboom, J. A. J., Nuijten, R. J. M., Wang, Y. X. G., Schroder, B., Heitkönig, I. M. A., et al. (2020). Will legal international rhino horn trade save wild rhino populations? Glob. Ecol. Conserv. 23:e01145. doi: 10.1016/j.gecco.2020.e 01145

Fang, Y., Yang, S., Zhou, S., Jiang, M., and Liu, J. (2013). Community pharmacy practice in China: past, present and future. Int. J. Clin. Pharm. 35, 520-528. doi: 10.1007/s11096-013-9789-5

Gao, Y., Stoner, K. J., Lee, A. T. L., and Clark, S. G. (2016). Rhino horn trade in China: an analysis of the art and antiques market. Biol. Conserv. 201, 343-347. doi: 10.1016/j.biocon.2016.08.001

Grasmick, H. G., and Bursik, R. J. (1990). Conscience, significant others, and rational choice: extending the deterrence model. Law Soc. Rev. 24, 837-861. doi: $10.2307 / 3053861$

Haas, T. C., and Ferreira, S. M. (2016). Combating rhino horn trafficking: the need to disrupt criminal networks. PLoS ONE 11:e0167040. doi: 10.1371/journal.pone.0167040

Hanley, N., Sheremet, O., Bozzola, M., and Macmillan, D. C. (2018). The allure of the illegal: choice modeling of rhino horn demand in Vietnam. Conserv. Lett. 11:e12417. doi: 10.1111/conl.12417

Hanson, M. E. (2011). Speaking of Epidemics in Chinese Medicine: Disease and the Geographic Imagination in Late Imperial China. Oxford: Routledge. doi: $10.4324 / 9780203829592$

Harfoot, M., Glaser, S. A. M., Tittensor, D. P., Britten, G. L., Mclardy, C., et al. (2018). Unveiling the patterns and trends in 40 years of global trade in CITESlisted wildlife. Biol. Conserv. 223, 47-57. doi: 10.1016/j.biocon.2018.04.017

Heckathorn, D. D. (2011). Snowball versus respondent-driven sampling. Sociol. Methodol. 41, 355-366. doi: 10.1111/j.1467-9531.2011. 01244.x

Humane Society International (2018). "Humane Society International Expresses Shock as China Lifts 25-Year-Old Ban on Tiger Bone and Rhino Horn Trade. Washington, DC. Available online at: http://www.hsi.org/news/press_releases/ 2018/10/humane-society-international-102918.html

Hutton, J. M., and Leader-Williams, N. (2003). Sustainable use and incentivedriven conservation: Realigning human and conservation interests. Oryx 37, 215-226. doi: 10.1017/S0030605303000395
Li, J., Shi, L., Liang, H., Ding, G., and Xu, L. (2018). Urban-rural disparities in health care utilization among Chinese adults from 1993 to 2011. BMC Health Serv. Res. 18:102. doi: 10.1186/s12913-018-2905-4

Li, P. (2007). Enforcing wildlife protection in China: the legislative and political solutions. China Inf. 21, 71-107. doi: 10.1177/0920203X07075082

Li, X., Lu, J., Hu, S., Cheng, K. K., De Maeseneer, J., Meng, Q., et al. (2017). The primary health-care system in China. Lancet 390, 2584-2594. doi: 10.1016/S0140-6736(17)33109-4

Lindsey, P. A., and Taylor, A. (2011). A Study on the Dehorning of African Rhinoceroses as a Tool to Reduce the Risk of Poaching. Endangered Wildlife Trust and South African Department of Environmental Affairs.

Ling, R. E., Liu, F., Lu, X. Q., and Wang, W. (2011). Emerging issues in public health: a perspective on China's healthcare system. Public Health 125, 9-14. doi: 10.1016/j.puhe.2010.10.009

Liu, C., and Wang, Y. (2020). 温病学理论指导下的新型冠状病毒肺炎诊治刍 议[Discussion on the application of febrile disease theory to the diagnosis and treatment of COVID-19]. 上海中医药杂志 [Shanghai Journal of Traditional Chinese Medicine] 54, 5-8.

Mayer, F. S., and Frantz, C. M. (2004). The connectedness to nature scale: a measure of individuals' feeling in community with nature. J. Environ. Psychol. 24, 503-515. doi: 10.1016/j.jenvp.2004.10.001

Mi, R., Shao, Z. Z., and Vollrath, F. (2019). Creating artificial rhino horns from horse hair. Sci. Rep. 9:16233. doi: 10.1038/s41598-019-52527-5

Moorhouse, T. P., Coals, P. G. R., D'cruze, N. C., and Macdonald, D. W. (2020). Reduce or redirect? Which social marketing interventions could influence demand for traditional medicines? Biol. Conserv. 242:108391. doi: 10.1016/j.biocon.2019.108391

Nagin, D. S. (2013). Deterrence in the twenty-first century. Crime Justice 42, 199-263. doi: 10.1086/670398

National Bureau of Statistics of China (2016). China Statistical Yearbook 2016. China Statistics Press and Beijing Info Press. Available online at: http://www. stats.gov.cn/tjsj/ndsj/2016/indexeh.htm

Newing, H. (2011). Conducting Research in Conservation: Social Science Methods and Practice. New York, NY: Routledge. doi: 10.4324/9780203846452

Oyanedel, R., Gelcich, S., and Milner-Gulland, E. J. (2020). Motivations for (non)compliance with conservation rules by small-scale resource users. Conserv. Lett. 13:e12725. doi: 10.1111/conl.12725

Paddock, L. C. (2012). Beyond deterrence: compliance and enforcement in the context of sustainable development. Environ. Law Rep. 42, 10622-10638. Available online at: https://elr.info/news-analysis/42/10622/beyonddeterrence-compliance-and-enforcement-context-sustainable-development

People's Republic of China (1989). 中华人民共和国野生动物保护法[Law of the People's Republic of China on the Protection of Wildlife (Amended in 2004)]. National People's Congress.

People's Republic of China (1993a).国务院关于禁止犀牛角和虎骨贸易的通 知[Circular of the State Council Banning Trade in Rhinoceros Horn and Tiger Bone]. State Council.

People's Republic of China (1993b). 林业部关于核准部分濒危野生动物为国家 重点保护野生动物的通知[Circular of the Department of Forestry Approving the Listing of Additional Endangered Species as Special Stated Protected Wildlife]. Department of Forestry (Defunct; Now State Forestry Administration).

People's Republic of China (2018a). Full Transcript: State Council Executive Deputy Secretary-General Ding Xuedong Answers Media Questions. China Internet Information Center. State Council Information Office and China International Publishing Group.

People's Republic of China (2018b). 国务院关于禁止犀牛角和虎骨贸易的通知 [Circular of the State Council on the Trade Ban Regarding Rhinoceros Horn and Tiger Bone]. State Council.

Phelps, J., Biggs, D., and Webb, E. L. (2016). Tools and terms for understanding illegal wildlife trade. Front. Ecol. Environ. 14, 479-489. doi: 10.1002/fee.1325

Rubino, E. C., and Pienaar, E. F. (2020). Rhinoceros ownership and attitudes towards legalization of global horn trade within South Africa's private wildlife sector. Oryx 54, 244-251. doi: 10.1017/S0030605318000030

Sheeran, P., and Webb, T. L. (2016). The intention-behavior gap. Soc. Pers. Psychol. Compass 10, 503-518. doi: 10.1111/spc3.12265

Smith, M. J., Benítez-Díaz, H., Clemente-Muñoz, M. Á., Donaldson, J., Hutton, J. M., Noel Mcgough, H., et al. (2011). Assessing the impacts of international 
trade on CITES-listed species: current practices and opportunities for scientific research. Biol. Conserv. 144, 82-91. doi: 10.1016/j.biocon.2010.10.018

Smith, R. J., Biggs, D., St. John, F. V.,'t Sas-Rolfes, M., and Barrington, R. (2015). Elephant conservation and corruption beyond the ivory trade. Conserv. Biol. 29, 953-956. doi: 10.1111/cobi.12488

Stephens, S., and Southerland, M. (2018). China's Role in Wildlife Trafficking and the Chinese Government's Response. US-China Economic and Security Review Commission Staff Research Report. Available online at: https://www.uscc.gov/ sites/default/files/Research/2018.12.06\%20-\%20Wildlife\%20Trafficking\%20\%20Final\%20Version.pdf

Sun, Q., Santoro, M. A., Meng, Q., Liu, C., and Eggleston, K. (2008). Pharmaceutical policy in China. Health Aff. 27, 1042-1050. doi: 10.1377/hlthaff.27.4.1042

't Sas-Rolfes, M., Challender, D. W. S., Hinsley, A., Veríssimo, D., and Milner-Gulland, E. J. (2019). Illegal wildlife trade: scale, processes, and governance. Ann. Rev. Environ. Resour. 44, 201-228. doi: 10.1146/annurev-environ-101718-033253

Tam, K.-P. (2013). Concepts and measures related to connection to nature: similarities and differences. J. Environ. Psychol. 34, 64-78. doi: 10.1016/j.jenvp.2013.01.004

Taylor, A., Balfour, D., Brebner, D. K., Coetzee, R., Davies-Mostert, H., Lindsey, P. A., et al. (2017). Sustainable rhino horn production at the pointy end of the rhino horn trade debate. Biol. Conserv. 216, 60-68. doi: 10.1016/j.biocon.2017.10.004

Thomas-Walters, L., Hinsley, A., Bergin, D., Doughty, H., Eppel, S., Macfarlane, D., et al. (2020). Motivations for the use and consumption of wildlife products. SocArXiv. doi: 10.1111/cobi.13578

Tittensor, D. P., Harfoot, M., Mclardy, C., Britten, G. L., Kecse-Nagy, K., Landry, B., et al. (2020). Evaluating the relationships between the legal and illegal international wildlife trades. Conserv. Lett. 13:e12724. doi: 10.1111/conl.12724

UNEP (2018). Official Statement on the Reversal of the Ban on Trade in Rhino and Tiger Parts by China. Available online at: https://www. unenvironment.org/news-and-stories/statement/official-statementreversal-ban-trade-rhino-and-tiger-parts-china (accessed September $16,2020)$.

Winter, S. C., and May, P. J. (2001). Motivation for compliance with environmental regulations. J. Policy Anal. Manage. 20, 675-698. doi: 10.1002/pam.1023
Wong, R. W. Y. (2016). The organization of the illegal tiger parts trade in China. Br. J. Criminol. 56, 995-1013. doi: 10.1093/bjc/azv080

Wong, R. W. Y. (2017). 'Do you know where I can buy ivory?': the illegal sale of worked ivory products in Hong Kong. Aust. NZ J. Criminol. 51, 204-220. doi: $10.1177 / 0004865817722186$

Wong, R. W. Y. (2019). China and the Illegal Wildlife Trade. Verlag: Springer International Publishing. doi: 10.1007/978-3-030-13666-6

Wright, O. T., Cundill, G., and Biggs, D. (2016). Stakeholder perceptions of legal trade in rhinoceros horn and implications for private reserve management in the Eastern Cape, South Africa. Oryx 52, 175-185. doi: $10.1017 /$ S.0030605316000764

WWF Global (2018). WWF Statement on China's Legalization of Domestic Trade in Tiger Bone and Rhino Horn. Available online at http://wwf.panda.org/wwf_ news/press_releases/?337353/WWF-statement-on-Chinas-legalization-ofdomestic-trade-in-tiger-bone-and-rhino-horn (accessed September 16, 2020).

Wyatt, T., Johnson, K., Hunter, L., George, R., and Gunter, R. (2018). Corruption and wildlife trafficking: three case studies involving Asia. Asian J. Criminol. 13, 35-55. doi: 10.1007/s11417-017-9255-8

Zhang, L., and Yin, F. (2014). Wildlife consumption and conservation awareness in China: a long way to go. Biodivers. Conserv. 23, 2371-2381. doi: 10.1007/s10531-014-0708-4

Zhang, S., Zhang, W., Zhou, H., Xu, H., Qu, Z., Guo, M., et al. (2015). How China's new health reform influences village doctors' income structure: evidence from a qualitative study in six counties in China. Hum. Resour. Health 13:26. doi: 10.1186/s12960-015-0019-1

Conflict of Interest: The authors declare that the research was conducted in the absence of any commercial or financial relationships that could be construed as a potential conflict of interest.

Copyright $\odot 2021$ Cheung, Mazerolle, Possingham and Biggs. This is an open-access article distributed under the terms of the Creative Commons Attribution License (CC $B Y)$. The use, distribution or reproduction in other forums is permitted, provided the original author(s) and the copyright owner(s) are credited and that the original publication in this journal is cited, in accordance with accepted academic practice. No use, distribution or reproduction is permitted which does not comply with these terms. 